\section{CarakaTani \\ Journal of Sustainable Agriculture \\ ISSN 2613-9456 (Print) 2599-2570 (Online)}

\title{
The Behavior and Performance of Cashew Market in South Buton Regency, Indonesia
}

\author{
Wa Ode Al Zarliani ${ }^{1 *}$, Wardana ${ }^{1}$ and Achmad Amiruddin ${ }^{2}$ \\ ${ }^{1}$ Department of Agribusiness, Faculty of Agriculture, Universitas Muhammadiyah Buton, \\ Baubau, Indonesia; ${ }^{2}$ Department of Agricultural Socio-economics, Faculty of Agriculture, \\ Universitas Hasanuddin, Makassar, Indonesia \\ *Corresponding author: alzarlianiwaode@gmail.com
}

\begin{abstract}
Some of the major problems in cashew marketing performance are low production, inefficient marketing system and low income received by farmers. In addition, farmer with a low bargaining position will only receive prices from market players in the midst of increasing demand and competition in the market. The aim of this study is to examine the behavior and performance of the cashew market in South Buton Regency, Indonesia. Furthermore, the marketing channels, margins, costs and benefits received by each agency were used to analyze the technical and economic efficiency. In addition, random and snowball sampling techniques were applied to determine the farmers and traders, respectively. The results showed that the behavior of market price was based on the cost analysis, supply and demand, as well as the expected benefit. Meanwhile, the transactions were made partially (initial payment before and after the products were sold) and some in cash. The market players were unique in providing cooperate capital to farmers. Moreover, the market performance shows an efficient system from the two channel patterns formed, close distance indicates a technically efficient system and low marketing cost indicates economic efficiency.
\end{abstract}

Keywords: financial analysis; market access; market players; supply chain

Cite this as: Al Zarliani, W. O., Wardana, \& Amiruddin, A. (2021). The Behavior and Performance of Cashew Market in South Buton Regency, Indonesia. Caraka Tani: Journal of Sustainable Agriculture, 36(1), 20-32. doi: http://dx.doi.org/10.20961/carakatani.v36i1.44216

\section{INTRODUCTION}

Cashew is one of the plantations that contribute to Indonesian economy and the main purposes of cashew plantation are reforestation and land protection, which have received no attention. However, in 1960s, after cashew was introduced to global market, the commodity was grown and developed in smaller form. The changes in management have encouraged cashew to serve as a source of foreign exchange and also income for farming community. At the beginning of Indonesia's agricultural development, cashew was planted for greening programs and reforestation (Widiatmaka et al., 2014) and further, this type of nut contributed to land conservation. In Indonesia, cashew was mostly cultivated by smallholders and the main problems in developing this commodity were the low productivity of Indonesian cashew crop and quality of product (Listyati and Sudjarmoko, 2011).

Cashew is also one of Indonesia's main export commodities, as reported by Fauziyah et al. (2017) that Indonesia was an exporter country with a good market share. Strategy of export competitiveness on cashew nuts can be applied by extending trade cooperation by joining and taking active role in the world trade organization, increasing cashew nuts productivity and socialization of information about international market of cashew nuts, exporting

\footnotetext{
* Received for publication September 7, 2020 Accepted after corrections October 21, 2020
} 
procedures, cashew nuts export, import policies and other rules related to transaction of cashew nuts export-import to all stakeholders. Each export activity should pay attention on both quality and quantity of exported commodity as there are many countries trading similar commodity in the international market. Therefore, exported commodity is suppose to have a strong competitiveness value (Fauziyah et al., 2017).

Cashew certainly has a high economic value and is quite potential because almost all of its parts can be utilized. This commodity has a significant contribution in increasing the country's foreign exchange and income sources of farming communities, as producers of raw materials for the food industry (Al Zarliani, 2019). The Indonesian agricultural export commodities, however, remain facing various challenges, most of them are very structural in nature, such as lowyielding smallholder crop systems, sustainability pressures, low-quality of production, underinvestment, inadequate infrastructure, underdeveloped agricultural practices and restrictive government policies (Arifin, 2013).

Southeast Sulawesi was one of the cashew suppliers in Indonesia in 2016, producing 28,657 tons (Direktorat Jendral Perkebunan, 2016). However, in recent years, the cashew commodity in this province decreases in productivity, caused by the occurrence of erratic climate change resulted from prolonged rainfall with hot sunlight (Al Zarliani, 2019). Bakhtiar et al. (2008) states that climate change causes the changes in weather, rainfall and atmospheric parameters, which affect the level of crop productivity. One of the causes of Indonesia's low contribution to the fulfillment of cashew nuts is the decrease in cashew nut production (Amir, 2013). The efforts to increase production can be carried out intensively but sometimes they fail due to unexpected climate changes (Noorhadi, 2012). In the study by Mog et al. (2019), the use of the growth inhibitor, paclobutrazol (PBZ), was very important. The PBZ treatment changed the physiology of cashew tree by modifying tree size, the growth of crown, segment length, branching pattern and overall soil cover. Higher total leaf chlorophyll content will contribute to better photo assimilation and increased leaf photosynthesis can contribute to early flowering and development of more flowering panicles with perfect blossoms. An increase in fruit count and the number of nuts $\mathrm{m}^{-2}$ of the canopy promote increased yields.

The ability to deliver maximum production followed by increased in sales volume will not ensure efficient marketing. Westlake (2005) states that marketing efficient is determined by the price, cost and profit received by farmers, producers and traders. Funke et al. (2012) confirms that the prevailing market price is strongly influenced by the forces of demand and supply or market behavior and the ability of buyers to bargain the production costs used and the margins received. Cashew nut business requires a very large capital. With large capital, cashew nuts and cashews can be purchased in large quantities so that a cash payment system can be applied. More capital owned by traders will contribute to more products that can be purchased. This will give a positive effect on the value of agricultural sector (Arsyad et al., 2019).

South Buton Regency is one of the cashewproducing areas in Southeast Sulawesi Province, Indonesia, where people work as farmers and use cashew farming as source of income. Based on the 2017 statistical data, South Buton had the capital with an area of 3,691 ha, a production of 709 tons and a productivity level of $192 \mathrm{~kg}$ $\mathrm{ha}^{-1}$. This is lower than those of the surrounding regencies, namely Buton with an area of 6,124 ha with 912 tons production and the Central Buton with an area of 11,743 ha with 1,819 tons production, as well as Muna with an area of 24,962 ha with 6,337 tons production (Direktorat Jendral Perkebunan, 2016). Based on the results, the production is not evenly distributed because some area produce maximum outputs while other areas only yield a minimal production. Therefore, it courses inefficient marketing system, as it is harmful to farmers and benefit traders. The emphasis of agricultural development should shift from agricultural sector to the manufacturing sector i.e. from the primary agricultural products into processed products (agro-industry), which may increase the value added, provide employment and expand the market of agricultural products (Herdhiansyah et al., 2012).

To develop sustainable agriculture, land management must be considered as one of the best management practices in the advancement of agricultural systems. Regional spatial planning, 
evaluation of land suitability for cashew nuts is carried out in the land mapping unit from the surveyed soil (Widiatmaka et al., 2015). Based on the phenomena taking place on the field, in which the producers (farmers) and traders (market players) try to negotiate in order to carry out marketing activities and to achieve effective marketing system, the authors are triggered to conduct a study on the behavior of cashew nut market, which includes price determination process, an applied payment system and the cooperation established among market players. Furthermore, the authors also perform an analysis of the cashew market performance, which includes marketing channels, margins, costs and profits as well as economic and technical efficiency of cashew marketing.

\section{MATERIALS AND METHOD}

This research was conducted in Batauga Sub-district, South Buton Regency, Southeast Sulawesi Province of Indonesia from April to May 2019, under the consideration that this area is one of the cashew production centers in Southeast Sulawesi, Indonesia. A total of 120 farmers cultivated cashew plants and 30 of them were taken as samples using a simple random sampling technique. Meanwhile, samples of traders, consisting of four village collecting traders and two large traders, were taken with snowball sampling technique.

This research applied descriptive qualitative and quantitative data analysis techniques. Qualitative data analysis was conducted to examine the market behavior and cashew marketing channel patterns. The market behavior covered pricing mechanisms, payment systems and marketing agency cooperation. Quantitative data analysis was performed to measure the market performance that comprised marketing system efficiency, technical efficiency and economic efficiency.

In a qualitative study, researchers require useful guidelines on how to analyze mass of qualitative data, but face a lack of clear guidelines for using specific analytical methods (de Casterlé et al., 2012). Quantitative Research Reporting Standards recommend some modifications to the original standards. Examples of modifications include division of hypotheses, analyses and conclusions into three groupings (primary, secondary and exploratory) and some changes to the section on meta-analysis (Appelbaum et al., 2018).

Market behavior can explain the activities required in pricing mechanisms, payment systems and cooperation between farmers and marketing institutions or the phenomena that occur between farmers and market players in the competition for getting cashew supply according to the amount of demand. The market performance in this study was examined from three functions, including marketing efficiency, technical efficiency and economical efficiency. Marketing margin was carried out quantitatively. The analysis was based on the primary data collected at every level from producers to consumers. It is the difference between the price paid by consumers and the price received by producers (Nurland, 1986). The higher the marketing cost is, the higher the marketing margin will be. Mathematically, the marketing margin was estimated using this formula.

Description:

$$
M=H e-H p
$$

$\mathrm{M}=$ Marketing margin stated in IDR $\mathrm{kg}^{-1}$

$\mathrm{He}=$ The retail price stated in IDR kg-1

$\mathrm{Hp}=$ Price at farmer level stated in IDR kg-1

Meanwhile, the amount of profit earned by each marketing agency involved was calculated using the following formula.

Description:

$$
M=B+\pi, \text { or } \pi=M-B
$$

$\mathrm{B}=$ Marketing costs stated in IDR kg-1

$\pi=$ The amount of profit withdrawn by the marketing agency stated in IDR kg-1

$\mathrm{M}=$ Marketing margin that in IDR kg-1

The marketing efficiency analysis was measured as follows.

Description:

$$
E P=\left[1-\frac{M}{H e}\right] \times 100 \%
$$

$\mathrm{EP}=$ Percentage of price received by farmers of the price paid by consumers (\%)

$\mathrm{M}=$ Marketing margin (IDR)

$\mathrm{He}=$ Price at trader level $\left(\right.$ IDR $\left.\mathrm{kg}^{-1}\right)$ 
Terms if:

Ep $\leq 50 \%$, the marketing system is not/not yet efficient;

Ep $>50 \%$, the marketing system is efficient

The market performance was carried out by analyzing the technical efficiency (T) and economic efficiency (E) by determining the economic efficiency index (EEI) and the technical efficiency index (TEI) using the formula as proposed by Calkins and Wang (1980).

1) $\mathrm{T}$ was calculated using the following formula:

$$
\mathrm{Tij}=\frac{\mathrm{Vij} / \mathrm{Wij}}{\mathrm{Dij}}
$$

2) E was calculated using the following formula:

Description:

$$
\text { Eij }=\frac{\Sigma k(\pi i j k)}{V i j}
$$

$\mathrm{T}=$ Marketing cost variable per final weight of sales per unit distance

$\mathrm{E}=$ The amount of agency profit per marketing cost variable

$\mathrm{V}=$ Marketing cost variable

$\mathrm{W}=$ The final sold weight

$\Pi=$ The amount of profit per marketing agency

$\mathrm{d}=$ The total distance traveled by the commodity

I = Type of commodity

$\mathrm{j} \quad=$ Types of marketing channels

$\mathrm{k}$ = Type of trader for commodity I in marketing channel $\mathrm{j}$

Test criteria:

Marketing channel $\mathrm{A}$ is considered more efficient than marketing channel $\mathrm{B}$ if the technical and economic efficiency index of channel $\mathrm{A}$ is smaller than B. To calculate the depreciation cost in the average marketing cost component of each marketing agency, the following formula was used:

$$
\text { Depreciation Cost }=\frac{\text { Depreciation Volume }}{\text { Sales Volume }} \times \text { Purchase Price }
$$

\section{RESULTS AND DISCUSSION}

Market behavior is a habit or activity carried out by village processing traders, large traders and village collecting traders for gaining profits. Activities they perform include pricing mechanism, payment systems and cooperation with marketing agencies. In sales activities, farmers sell the cashews to village processing traders, village collecting traders, processing farmers and large traders. When bargaining takes place between farmers and traders, the pricing mechanism is influenced by an analysis of costs incurred, the level of profit received, winning the competition, market demand and the availability of cashew supply. These findings are in line with the outcomes of study by Shumeta et al. (2012), which explains that the main factors considered in determining prices are the demand and supply situation. In conducting transactions, farmers and village collecting traders implement a cash payment system.

However, village collecting traders to large traders carry out a partial payment system as well as cash payments that are adjusted to the amount of cashew supply offered. Dinh et al. (2017) researched that to increase the supply of cashew, economic incentives were needed. The result is that tree planting is financially more profitable than leaving abandoned land. Nevertheless, the decision and intensity of tree planting by rural households are influenced by various factors that represent household characteristics, farming, biophysical factors, social institutional support and farmers' perceptions of the risk of expropriation of forest land.

Market players try to maintain business continuity in cooperation. The cooperation is in the form of providing capital to farmers and therefore, there is a cooperation agreement by selling cashews to market players. Furthermore, the cooperation that exists among village collecting traders is in terms of transportation when cashews are being sold to large traders. Smallholder farmers can access the market, either by selling at the farm gate or physically transporting produce using available means to the market place. A number of scholars have studied the drivers of market access (Kyomugisha 
et al., 2018). The cooperation built is usually based on the length of time the traders carry out buying and selling activities and mutual trust related to family relationships.

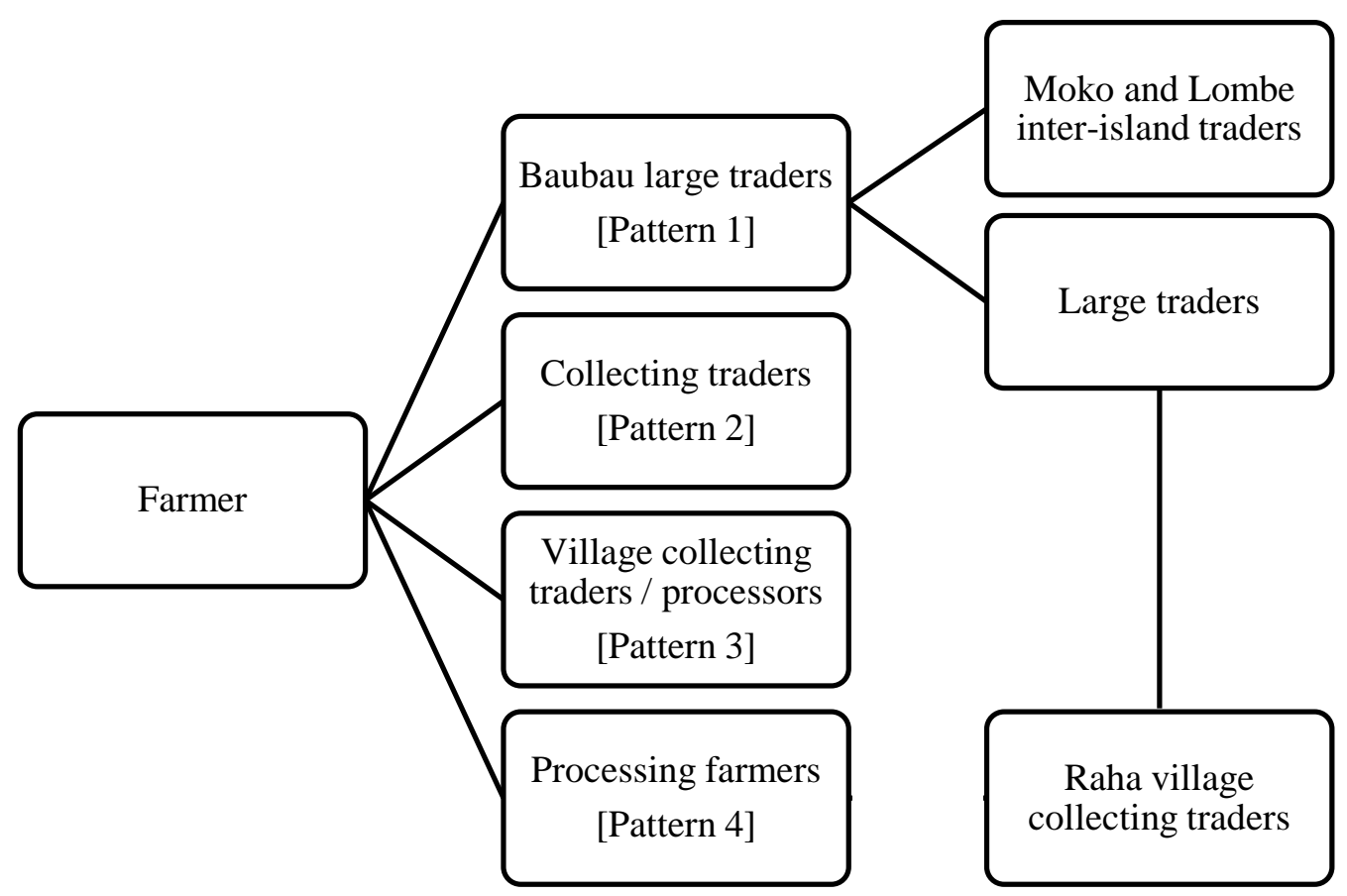

Figure 1. Raw cashew marketing channels in Lawela Village, South Buton Regency (Al Zarliani, 2020)

\section{Marketing channel pattern 1}

The information in pattern I (Figure 1) shows that farmers directly sell cashews to large traders in the Baubau City people market. It can be explained that farmers often carry out sales activities when buying various necessities at the People Market, which is a selling place of large traders. Farmers sell raw cashews with a weight range of between $20 \mathrm{~kg}$ and $50 \mathrm{~kg}$. The large trader collects raw cashews by weighing, bulking and putting them back in the sacks by hiring employees who are given daily wages in accordance with the amount of raw cashew supply that can be purchased at that time. The wages given to employees who help are IDR $50 \mathrm{~kg}^{-1}$ and thus, for every purchase of 1 ton of raw cashews, they are paid IDR 50,000. After the cashews are collected, the large trader sells the cashews to the inter-island traders in Central Buton Regency (Moko and Lombe Villages).

Several factors that can influence cashew nut marketing according to the study by Nyambo and Ligate (2013) are role model farmers (RMFs), extensionists, radio, on-farm demonstrations, researchers, cashew development centers (CDCs), print media and mobile phones in order of popularity. In other studies highlighting the aspects of the experience in marketing, the invested capital in the campaign, the cost of commercial labor and the category of commercial actor determine the level of economic profitability of cashew nuts marketing (Aïhounton et al., 2016). The dominant factors in cashew nut marketing in Buton Regency is the experience and network of a farmer or trader. These affect the level of efficiency in distributing the products to consumers. Information regarding supply and demand is widely available and thus, it is appropriate in making distribution decisions. The marketing agencies involved in the cashew marketing in pattern I are farmers, large traders and Moko inter-island traders. The costs, margins and profits of each marketing agency can be explained as follows:

\section{Analysis for margin, costs and profits of large traders pattern 1}

Large traders in the pattern 1 marketing channel are traders who buy cashews from farmers whose marketing function activities are 
the same as those of the receiving traders in the pattern 2 marketing channel. Table 1 shows that the large traders purchase cashews with varying prices around IDR $20,000 \mathrm{~kg}^{-1}$ and IDR $24,000 \mathrm{~kg}^{-1}$, the average purchase price of IDR $22,000 \mathrm{~kg}^{-1}$ and the average selling price to inter-island traders of IDR $23,000 \mathrm{~kg}^{-1}$ with a price range of IDR $21,000 \mathrm{~kg}^{-1}$ and $25,000 \mathrm{~kg}^{-1}$. The margins, costs and profits received by each marketing agency involved in cashew marketing in pattern 1 marketing channels can be seen in Table 1 .

Table 1. Analysis of margins, costs and profits of marketing agencies in cashew marketing channels pattern 1 in 2019

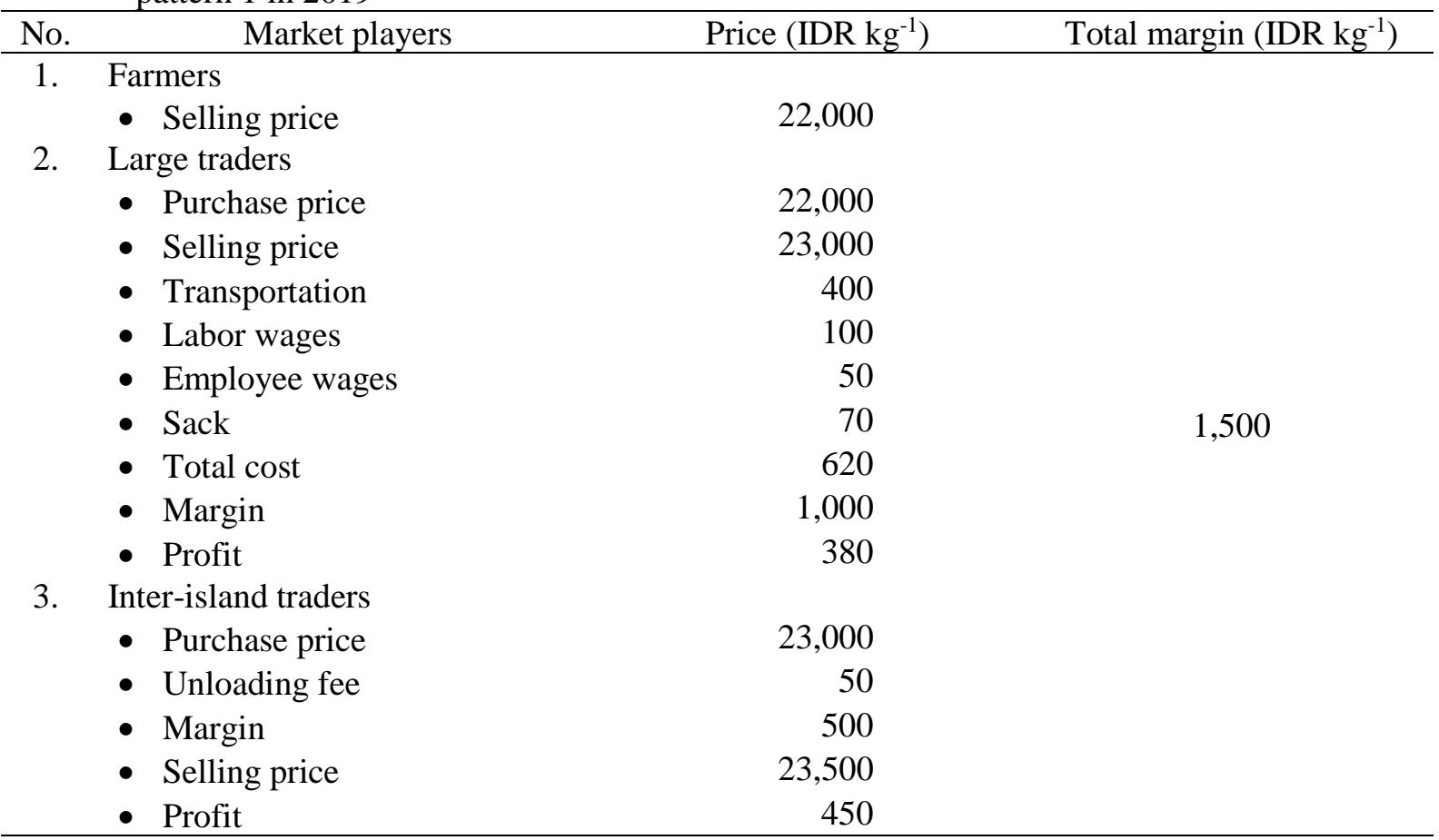

The process of selling cashews by large traders depends on the results of agreements with interisland traders. In this case, inter-island traders under particular situations purchase cashews by visiting large traders in traditional market. It means that large traders will pay the transportation costs, as well as the labor wages, including loading and unloading and vice versa, if the large traders carry out the marketing function by sending cashews. Good marketing process triggering commercialization and unsuccessful in this step leads to inadequate income (Mariyono et al., 2018). The agreement result will determine the selling price prevailing at the respective trader level.

Agyemang et al. (2018) research that examines the cashew nut supply chain highlights that in the short term, kernel distributors need to overcome three main operational obstacles, including a lack of internal top-level management commitment, a lack of integrated management and traceability information systems and the uncertainty of economic benefits. In addition, barriers such as difficulties in assessing environmental performance and lack of consumer demand for green cashews must be overcome in the long term. The key word here is productivity, in which a farmer must be able to measure and know how to treat cashews, which will yield high production. The government's role is also needed in assisting farmers by providing information on cashew nut cultivation and giving assistance to their needs. In marketing channel 1, the most significant factor is transportation. This is because cashew nuts have to be transported by ship to trade between islands. The higher the transportation cost is, the higher the cashew nut price will be (Adeio et al., 2018).

\section{Analysis for margin, cost and profits of inter- island traders pattern 1}

Inter-island traders buy cashews from large traders and sell some of the cashews back to processing farmers and processors. The amount 
of cashews that is sold is an average of 20 tons per season. These inter-island traders also carry out processing activities by appointing employees who are given wages. Information in Table 1 shows that inter-island traders buy cashews at an average price of IDR $23,000 \mathrm{~kg}^{-1}$ and resell them at IDR $23,500 \mathrm{~kg}^{-1}$. In this condition, it can be explained that inter-island traders only pay the unloading costs of cashew nuts upon arrival at the inter-island traders' place of IDR $50 \mathrm{~kg}^{-1}$, with the margin received of IDR $500 \mathrm{~kg}^{-1}$ and the profit received of IDR $450 \mathrm{~kg}^{-1}$.

The profits received by large traders are smaller than those received by inter-island traders. This is because the large traders incur higher costs, especially the costs of transporting cashews and labor costs when buying cashews from outside Southeast Sulawesi, where cashew transactions are conducted at Murhum port, Baubau. The cost component is a factor that affects the size of profits received by each marketing agency. Production inputs will affect the selling price of cashew. More treatments for a product will contribute to higher selling price. This is in line with Liu's et al. (2019) research, which confirms that land size, machine ownership, sales ability and level of cooperative demonstration are the main factors that determine members' decisions to use agricultural cooperatives as marketing channels and users of marketing channels get significantly higher farm income.

The greater the costs incurred is, the smaller the profit received by the traders involved will be. Thus, it can be said that the more marketing function activities carried out by the marketing agency, the greater the costs incurred. This is in line with the findings of study by Limbong and Sitorus (1987) that the costs incurred by a trading agency in the process of distributing a commodity depend on the trading functions performed. The difference in the functions performed by each trading agency results in the differences in selling prices from one institution to another to the end consumer. Furthermore, Soekartawi (1989) declares that the amount of marketing costs is different from one another. This is attributed to (1) various commodities, (2) marketing locations, (3) various marketing agencies and (4) the effectiveness of marketing carried out. The government needs to pay a special attention to the increasing of cashew nut production as a regional potential commodity, as suggested in de Alencar et al. (2018) research, when governmental policies oriented to exportation began to encourage cashew nut production in large monoculture fields. Since then, cashew cultivation has been expanded by the nut industry and recently, small settlement farmers have started to cultivate dwarf cashew tree clones.

\section{Pattern 2 marketing channel}

The pattern 2 (Figure 1) marketing channel provides information that farmers sell raw cashews to village collecting traders in Lawela Village, South Buton Regency, whose marketing activities only accept raw cashews (do not carry out stripping activities). The collected cashews are then sold back to large traders in Baubau City. Subsequently, the large traders sell the cashews to collecting traders in Labasa Village, Muna Regency and collecting traders in Moko Village, Central Buton Regency. Pricing transactions occur as a result of communication between traders. Sometimes, village collectors (lawela) directly carry out transaction activities with wholesalers and at certain times, the wholesalers entrust shipments by car to the village, where the traders are in Raha City.

\section{Analysis for margin, costs and profits of marketing agencies pattern 2}

Marketing agencies involved in raw cashew marketing in pattern 2 marketing channel are village collecting traders and large traders in Baubau (Table 2). Meanwhile, large traders pay a total cost of IDR $200 \mathrm{~kg}^{-1}$, which is distributed to the cost of transporting cashews at the village collecting trader level of IDR $150 \mathrm{~kg}^{-1}$ and labor wages of IDR $50 \mathrm{~kg}^{-1}$. Therefore, the marketing margin is IDR 500 and the profit received is IDR $300 \mathrm{~kg}^{-1}$. Table 2 demonstrates that the large traders sell cashews to Raha Village collecting traders with an average selling price of IDR 24,500 and a price range of IDR 22,000-IDR 27,000 $\mathrm{kg}^{-1}$. In this condition, village collecting traders buy cashews from large traders by spending transportation costs, including crossing costs of IDR $500 \mathrm{~kg}^{-1}$ and labor costs, including loading and unloading of IDR $150 \mathrm{~kg}^{-1}$ and therefore, the total costs incurred are IDR $650 \mathrm{~kg}^{-1}$. 
Table 2. Margins, costs and profits of marketing agencies in pattern 2 marketing channel

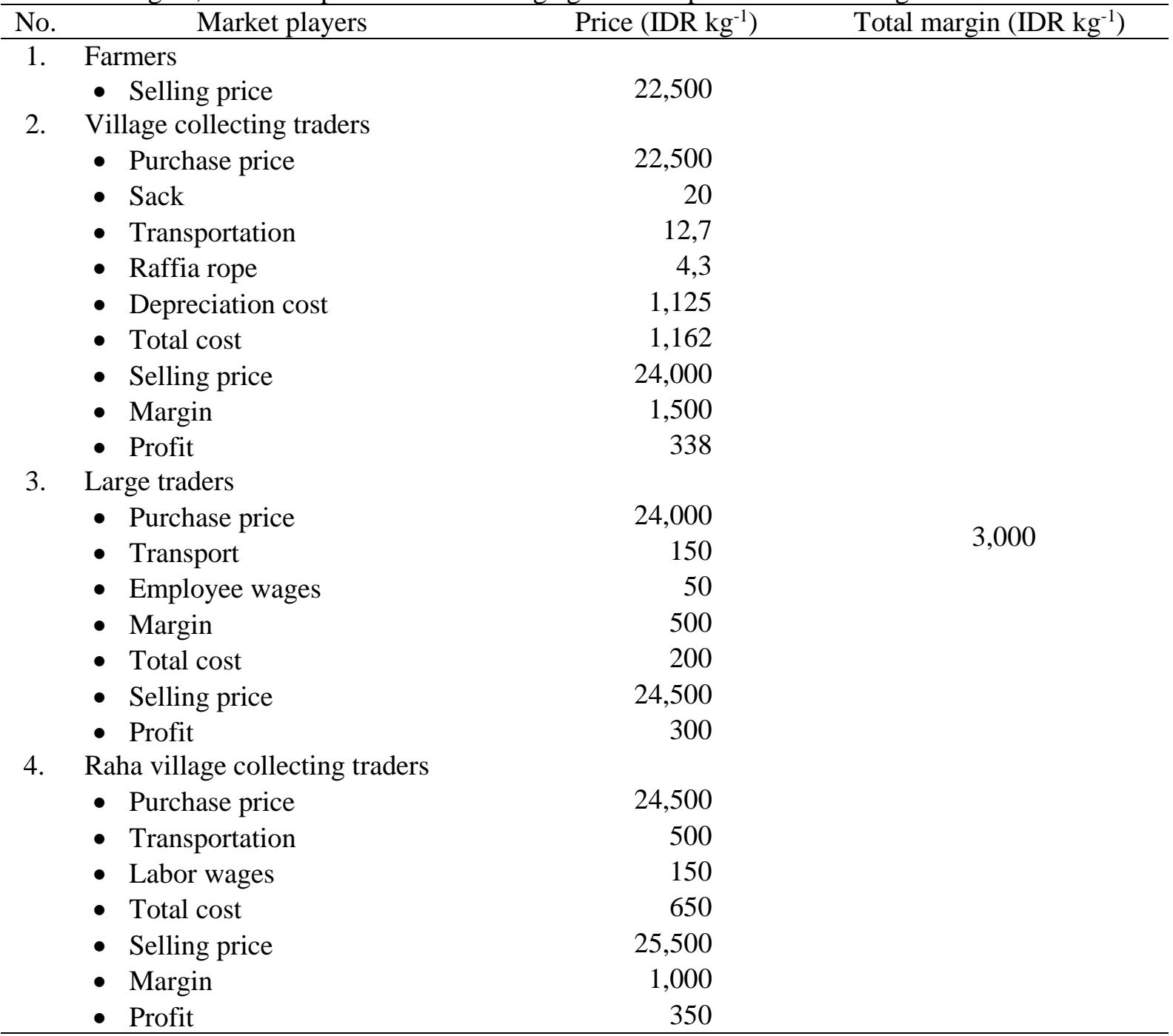

The cashews that are purchased are then dried and shelled by village collecting traders and some are sold directly to processing farmers and other traders without drying with an average selling price of IDR $25,500 \mathrm{~kg}^{-1}$ and a price range of IDR 23,000 - IDR 28,000 $\mathrm{kg}^{-1}$. The marketing margin is IDR $1,000 \mathrm{~kg}^{-1}$ with a profit of IDR $350 \mathrm{~kg}^{-1}$. From the analysis results, it is obtained a total margin of IDR 2,500, which is greater than the margin in the pattern 1 marketing channel. This is because the pattern 2 involves more traders with a long distance and therefore, it requires a large cost, which has an impact on higher selling prices and large margin differences that affect the resulting profit and marketing efficiency. This is in line with the conclusion of the study by Suratiyah (2006) that the size of marketing costs varies, depending on the activity and location of the business.
Additional activities to increase the selling value are farmers' efforts to get bigger profits. These must be supported by public policies that promote growth in the productivity of food crops that may be more effective in achieving better economic performance and poverty reduction (Gero and Egbendewe, 2020). One of the similar examples is a program set by the Indian government in support of increasing agricultural productivity, by building Agri-Clinic and Agri-Business Centers with the factors of planning orientation, work orientation, personal efficacy, market orientation, location, business acumen, dynamism, service orientation, in-depth knowledge, achievement motivation, social networks, interest, internal control, marketing strategy and innovativeness. The results of the factor analysis seemed to be consistent with the theory of entrepreneurial motivation 
and the entrepreneurial behavior patterns of successful entrepreneurs (Chandrashekar and Bahal, 2012).

\section{Pattern 3 marketing channel}

Marketing channel pattern 3 (Figure 1) presents that farmers directly sell cashews to collectors or processors in village. The collectors then carry out the function of drying and storing the cashews, as well as drying parts of the cashews for two days and shelling them (no margin). The evolution in the agricultural sector and the new challenges it faces, efficiently managing agricultural supply chains, have become interesting topics. The integration of the uncertainty aspect continues to be important for managerial decision making because it can lead to increased efficiency, responsiveness, business integration and ultimately in market competitiveness (Borodin et al., 2016).

\section{Margins, costs and profits of village collecting traders/processors pattern 3}

Traders involved in the cashew marketing in the pattern 3 marketing channel are village collecting traders or processors. In this condition, there is no marketing margin or costs incurred because village collecting traders are the end consumers of cashews. In other words, they no longer carry out cashew sales activities, but they dry and store the collected cashews and then peel them according to the conditions of favorable cashew prices and when they need money to fulfill their daily needs. Farmers sell the cashews to village collecting traders or processors with an average selling price of IDR $22,500 \mathrm{~kg}^{-1}$ and a price range of IDR 20,000-IDR $25,000 \mathrm{~kg}^{-1}$. Information about contemporary Food Supply Chains (FSCs) activities to consumers is necessary, because FSCs must provide adequate information that consumers and other relevant agencies need to know, such as variations in food attributes, country of origin, animal welfare and problems related to genetic engineering. For this reason, an effective food traceability system (FTS) is important (Bosona and Gebresenbet, 2013).

\section{Pattern 4 marketing channel}

The pattern 4 (Figure 1) marketing channel is similar to pattern 3, where farmers directly sell cashews to processing farmers in one regency. Processing farmers are basically cashew farmers who have the expertise to process and have the capital to purchase raw cashews from other farmers. They carry out purchasing activities with considerations that raw cashews produced from their own gardens are relatively small in number. Furthermore, cashew processing is more profitable than selling it back to large traders. In other words, processing farmers are the end consumers of the pattern 4 marketing channel in Laweala Village. The lack of reference price information is often regarded as one of the most pervasive aspects of incomplete commodity markets in developing countries (Belay and Ayalew, 2020).

\section{Margins, costs and profits of village collecting traders / processors pattern 4}

The traders involved in the pattern 4 marketing channel are farmers and processing farmers. In this condition, farmers sell cashews to processing farmers at an average price of IDR $22,500 \mathrm{~kg}^{-1}$ with a price range of IDR 20,000 IDR $25,000 \mathrm{~kg}^{-1}$. In the pattern 4 marketing channel, there is no cashew selling activity and therefore, there is no marketing margin or costs incurred because processing farmers buy cashews to be shelled to produce processed cashew nuts. Design of a supply chain management is a constrained optimization problem. Many insights about supply chain management design can be obtained from static profit maximization problems subject to relevant constraints (Ableeva et al., 2019).

\section{Cashew marketing efficiency in Lawela Village, South Buton Regency in 2019 \\ Cashew marketing in Lawela Village is carried} out through four marketing channel patterns. However, the largest marketing margin is in pattern 2 of IDR $3,500 \mathrm{~kg}^{-1}$, while pattern 1 receives a margin of IDR $1,500 \mathrm{~kg}^{-1}$. The total marketing margin for pattern 1 is IDR $1,500 \mathrm{~kg}^{-1}$, distributed to large traders with a margin of IDR $1,000 \mathrm{~kg}^{-1}$ or $66.67 \%$ and inter-island traders with a margin of IDR $500 \mathrm{~kg}^{-1}$ or $33.33 \%$. The low margin value is because inter-island traders only take a small profit per kilogram of cashews sold. In this condition, inter-island traders purchase cashew nuts from village collecting traders with the purpose of shelling the cashews and producing cashew nuts, which are then sold to Jakarta and Baubau retailers. The analysis results presented in Table 3 show that the percentage value of the price received by farmers from the price 
paid by consumers (collecting traders) in Labasa Village is $92 \%$. This value indicates that the cashew marketing system in the pattern 1 marketing channel is efficient. It means that $92 \%$ of the price paid by consumers is also enjoyed by producer farmers.

The pattern 2 marketing channel receives a total margin of IDR $3,000 \mathrm{~kg}^{-1}$, which is distributed to village collecting traders of
IDR $1,500 \mathrm{~kg}^{-1}$ or $50 \%$, Baubau large traders of IDR $500 \mathrm{~kg}^{-1}$ or $16.67 \%$, and Labasa Village collecting traders of IDR $1,000 \mathrm{~kg}^{-1}$ or $33.33 \%$. Based on the analysis results in the EP of $89 \%$. It means that from $100 \%$ of the price received by traders as intermediaries with consumers, $89 \%$ is enjoyed and felt by farmers, who are cashew producers. The total margin of each marketing agency in Lawela Village is presented in Table 3.

Table 3. Margins, costs and efficiency of cashew marketing in Lawela Village, South Buton Regency, 2019

\begin{tabular}{cccc}
\hline Marketing channel pattern & Marketing margin & Trader's selling price & $\mathrm{EP}=1-\mathrm{M} / \mathrm{He} \times 100 \%$ \\
\hline Pattern 1 & 1,500 & 23,500 & 94 \\
Pattern 2 & 3,000 & 25,500 & 89 \\
Pattern 3 & 0 & 0 & 0 \\
Pattern 4 & 0 & 0 & 0 \\
\hline
\end{tabular}

The patterns 3 and 4 do not have a marketing margin because cashews purchased by village collecting traders and processing farmers are not resold but are dried in the sun to be shelled and produced into cashew nuts. Thus, the cashew marketing margin for patterns 3 and 4 does not exist. The margin will be analyzed in the cashew nut marketing margin. The results of marketing efficiency (Farmer Share) show that the cashew marketing system in Lawela Village is already efficient and the most efficient one is the pattern 1 marketing channel. This is because the marketing chain is shorter and it involves some traders, compared to pattern 2 and the costs incurred are smaller and hence, the margins obtained is also smaller.

The explanation is in line with Hanafiah and Saefuddin (1986), who state that farmers' shares are inversely proportional to marketing margin, in which the smaller the marketing margin received is, the greater the percentage of price received by farmers will be. Linking smallholder farmers to markets and making markets work for the poor is increasingly becoming an important part of the global research and development agenda. Organizations have used various strategies to link farmers to markets. These approaches have mainly been evaluated for their potential to increase participation in markets and household incomes (Njuki et al., 2011).

\section{Technical efficiency and economic efficiency}

The marketing channel pattern 2 based on the information in Table 4 exposes that the distance to the last buyer is $53.63 \mathrm{~km}$ with a total cost of IDR $2,012 \mathrm{~kg}^{-1}$. The results show the technical efficiency index of 39.49 , meaning that every one kilometer of cashew marketing channel mileage to the end buyer incurred a cost of IDR 39.49, while the economic efficiency index was 0.49 , meaning that each cost incurred of IDR 1 would provide a profit of IDR 0.49 .

Table 4. Technical and economic efficiency in cashew marketing channels in Lawela Village, South Buton Regency, 2019

\begin{tabular}{ccccccc}
\hline $\begin{array}{c}\text { Channel } \\
\text { pattern }\end{array}$ & $\begin{array}{c}\text { Marketing } \\
\text { costs (Vij) }\end{array}$ & $\begin{array}{c}\text { Final weight } \\
(\text { Wij })\end{array}$ & $\begin{array}{c}\text { Transport } \\
\text { distance }(\text { dij })\end{array}$ & $\begin{array}{c}\text { Total profits } \\
\left(\sum \pi \mathrm{ijk}\right)\end{array}$ & $\begin{array}{c}\text { Technical } \\
\text { efficiency (Tij) }\end{array}$ & $\begin{array}{c}\text { Economic } \\
\text { efficiency (Eij) }\end{array}$ \\
\hline 1 & 670 & 1 & 39.52 & 830 & 16.95 & 1.23 \\
2 & 2,012 & 0.95 & 53.63 & 988 & 39.49 & 0.49 \\
3 & 0 & 0 & 0.05 & 0 & 0 & 0 \\
4 & 0 & 0 & 0 & 0 & 0 & 0 \\
\hline
\end{tabular}

Overall, it can be concluded that economically, the most efficient marketing channel is pattern 1. This is based on the technical efficiency index value of 16.95 , which is smaller than that of the pattern 2 and the technical efficiency index value of 39.49. The research results are in line 
with the outcomes of the study by Calkins and Wang (1980) that the marketing channel with the closest distance produces the lowest efficiency index and can be stated as the most efficient marketing channel.

\section{CONCLUSIONS}

Market behavior shown by the cashew market players in Batauga Sub-district, Southeast Sulawesi is based on four things, namely 1) cost analysis, 2) availability of cashew supply, 3 ) opportunities to win market competition and 4) expected profits. Government should give serious attention and support the availability of knowledgeable extensionists and the farmers that are serious and care about government programs by making farming activity as a commercial business, instead of merely a part of life. Strong cooperation between farmers is required for avoiding manipulation by traders as market players, who act as price determinants and decision makers.

\section{REFERENCES}

Ableeva, A. M., Salimova, G. A., Rafikova, N. T., Fazrahmanov, I. I., Zalilova, Z. A., Lubova, T. N., Nigmatullina, G. R., Girfanova, I. N., Farrakhova, F. F., \& Hazieva, A. M. (2019). Economic evaluation of the efficiency of supply chain management in agricultural production based on multidimensional research methods. International Journal of Supply Chain Management, 8(1), 328-338. Retrieved from https://ojs.excelingtech.co.uk/ index.php/IJSCM/article/view/2899

Adeio, P. E., Adejo, E. G., \& Zakari, J. (2018). Evaluation of the profitability and performance of youth participation in cashew nut (Anacardium occidentale) marketing in Ankpa local government area of Kogi State, Nigeria. Journal of Asian Rural Studies, 2(1), 49-56. http://dx.doi.org/10.20956/jars.v2i1.1 364

Agyemang, M., Zhu, Q., Adzanyo, M., Antarciuc, E., \& Zhao, S. (2018). Evaluating barriers to green supply chain redesign and implementation of related practices in the West Africa cashew industry. Resources, Conservation and Recycling, 136, 209-222. https://doi.org/10.1016/j.resconrec.2018.04.0 11
Aïhounton, D. G. B., Yabi, J. A., Bachabi, F. X., Yegbemey, R. N., Kindemin, A. O., \& Labiyi, I. (2016). Socio-economic determinants of the economic profitability of cashew nuts marketing in North-Eastern-Benin: Case study of Tchaourou municipality. International Journal of Innovation and Scientific Research, 21(1), 212-219. Retrieved from http://www. issr-journals.org/links/papers.php?journal=iji sr\&application=pdf\&article=IJISR $-15-351-03$

Al Zarliani, W. O. (2019). Cashew market behavior with environmental considerations in Southeast Sulawesi. IOP Conference Series: Earth and Environmental Science, 343(1), 12142. https://doi.org/10.1088/1755-1315/343 /1/012142

Al Zarliani, W. O. (2020). Analysis of cashew nut marketing channel in Southeast Sulawesi Province. 1st Borobudur International Symposium on Humanities, Economics and Social Sciences (BIS-HESS 2019), 171-175. https://doi.org/10.2991/assehr.k.200529.036

Amir, M. S. (2013). Ekspor impor teori dan penerapannya. Jakarta: PT Pustaka Binaman Pressindo (PPM).

Appelbaum, M., Cooper, H., Kline, R. B., MayoWilson, E., Nezu, A. M., \& Rao, S. M. (2018). Journal article reporting standards for quantitative research in psychology: The APA Publications and Communications Board task force report. American Psychologist, 73(1), 325. https://dx.doi.org/10.1037/amp0000191

Arifin, B. (2013). On the competitiveness and sustainability of the Indonesian agricultural export commodities. ASEAN Journal of Economics, Management and Accounting, 1(1), 81-100. Retrieved from https://fem.ipb. ac.id/miicema/e-journal2/wp-content/uploads/ 2015/09/6.pdf

Arsyad, M., Muis, M., \& Sabang, Y. (2019). Government expenditure and private investment on the value of agricultural sector in labor absorption. International Journal of Innovative Technology and Exploring Engineering (IJITEE), 8, 496-501. Retrieved from https://www.ijitee.org/wp-content/uploa ds/papers/v8i7s2/G10840587S219.pdf

Bakhtiar, I., Santoso, H., Hafild, E., \& Novira, R. (2008). Perubahan iklim, hutan, dan REDD: 
Peluang atau Tantangan. Bogor: CSO Network on Forestry Governance and Climate Change, The Partrnership for Governance Reform. Retrieved from https://scholar.google.co.id/scholar?cluster=2 $431428309955472672 \&$ hl $=$ id\&as_sdt=2005\& sciodt $=0,5 \&$ authuser $=3$

Belay, D. G., \& Ayalew, H. (2020). Nudging farmers in crop choice using price information: Evidence from Ethiopian Commodity Exchange. Agricultural Economics, 51(5), 793-808. https://doi.org/10.1111/agec.12592

Borodin, V., Bourtembourg, J., Hnaien, F., \& Labadie, N. (2016). Handling uncertainty in agricultural supply chain management: A state of the art. European Journal of Operational Research, 254(2), 348-359. https://doi.org/ 10.1016/j.ejor.2016.03.057

Bosona, T., \& Gebresenbet, G. (2013). Food traceability as an integral part of logistics management in food and agricultural supply chain. Food Control, 33(1), 32-48. https:// doi.org/10.1016/j.foodcont.2013.02.004

Calkins, P. H., \& Wang, H. (1980). Improving the marketing of perishable commodities: a case study of selected vegetables in Taiwan. Shanhua, Tainan: AVRDC. Retrieved from https://worldveg.tind.io/record/9724

Chandrashekar, S., \& Bahal, R. (2012). Factors influencing the entrepreneurial behaviour of agricultural graduates. SAARC Journal of Agriculture, 10(2), 31-39. https://doi.org/ 10.3329/sja.v10i2.18321

de Alencar, P. G., de Espindola, G. M., \& da Costa Carneiro, E. L. N. (2018). Dwarf cashew crop expansion in the Brazilian semiarid region: Assessing policy alternatives in Pio IX, Piauí. Land Use Policy, 79, 1-9. https://doi.org/ 10.1016/j.landusepol.2018.07.042

de Casterlé, B. D., Gastmans, C., Bryon, E., \& Denier, Y. (2012). QUAGOL: A guide for qualitative data analysis. International Journal of Nursing Studies, 49(3), 360-371. https:// doi.org/10.1016/j.ijnurstu.2011.09.012

Dinh, H. H., Nguyen, T. T., Hoang, V.-N., \& Wilson, C. (2017). Economic incentive and factors affecting tree planting of rural households: Evidence from the Central Highlands of Vietnam. Journal of Forest
Economics, 29, 14-24. https://doi.org/10.1016 /j.jfe.2017.08.001

Direktorat Jendral Perkebunan. (2016). Statistik perkebunan Indonesia 2015 - 2017: Jambu mete. Retrieved from http://ditjenbun.perta nian.go.id/?publikasi=buku-publikasi-statistik $-2015-2017$

Fauziyah, E., Aniyatussholihah, A., \& Hidayati, D. R. (2017). Strategy of export competitiveness enhancement on cashew nut commodity. JEJAK: Jurnal Ekonomi Dan Kebijakan, 10(2), 302-316. https://doi.org/ 10.15294/jejak.v10i2.11295

Funke, O., Raphel, B., \& Kabir, S. (2012). Market structure, conduct and performance of gari processing industry in South Western Nigeria. European Journal of Business and Management, 4(2), 99-113. Retrieved from https://iiste.org/Journals/index.php/EJBM/arti cle/view/1039

Gero, A. A., \& Egbendewe, A. Y. G. (2020). Macroeconomic effects of semi-subsistence agricultural productivity growth: Evidence from Benin and extension to the WAEMU countries. Scientific African, 7, e00222. https://doi.org/10.1016/j.sciaf.2019.e00222

Hanafiah, A. M., \& Saefuddin, A. M. (1986). Tataniaga hasil pertanian. Jakarta: Universitas Indonesia.

Herdhiansyah, D., Sutiarso, L., Purwadi, D., \& Taryono, T. (2012). Strategi pengembangan potensi wilayah agroindustri perkebunan unggulan. Jurnal Teknik Industri, 13(2), 201209. https://doi.org/10.22219/JTIUMM.Vol1 3.No2.201-209

Kyomugisha, H., Sebatta, C., \& Mugisha, J. (2018). Potato market access, marketing efficiency and on-farm value addition in Uganda. Scientific African, 1, e00013. https://doi.org/10.1016/j.sciaf.2018.e00013

Limbong, W. H., \& Sitorus, P. (1987). Pengantar tataniaga pertanian. Bahan Kuliah. Jurusan Ilmu-Ilmu Sosial Ekonomi Pertanian. Fakultas Pertanian. Institut Pertanian Bogor. Bogor. Retrieved from https://scholar.google.com/ scholar?cluster $=680439204011283637 \& \mathrm{hl}=\mathrm{e}$ n\&oi=scholarr

Listyati, D., \& Sudjarmoko, B. (2011). Economic 
value added of cashew processing in Indonesia. Jurnal Tanaman Industri dan Penyegar (JTIDP), 2(2), 231-238. Retrieved from http://ejurnal.litbang.pertanian.go.id/ind ex.php/bultri/article/view/555

Liu, Y., Ma, W., Renwick, A., \& Fu, X. (2019). The role of agricultural cooperatives in serving as a marketing channel: evidence from lowincome regions of Sichuan province in China. International Food and Agribusiness Management Review, 22(2), 265-282 https:// doi.org/10.22434/IFAMR2018.0058

Mariyono, J., Dewi, H. A., Daroini, P. B., Latifah, E., Zakariya, A. Z., \& Afari-Sefa, V. (2018). Marketing aspects of vegetables: Comparative study of four regions in East Java and Bali. Agriekonomika, 7(1), 46-56. https://doi.org/ 10.21107/agriekonomika.v7i1.3410

Mog, B., Janani, P., Nayak, M. G., Adiga, J. D., \& Meena, R. (2019). Manipulation of vegetative growth and improvement of yield potential of cashew (Anacardium occidentale L.) by Paclobutrazol. Scientia Horticulturae, 257, 108748. https://doi.org/10.1016/j.scienta. 2019.108748

Njuki, J., Kaaria, S., Chamunorwa, A., \& Chiuri, W. (2011). Linking smallholder farmers to markets, gender and intra-household dynamics: does the choice of commodity matter?. The European Journal of Development Research, 23(3), 426-443. https://doi.org/10.1057/ejdr.2011.8

Noorhadi, N. (2012). Kajian macam dan tebal musa organik terhadap iklim mikro pada tanaman kacang tanah (Arachis hypogaea L. Merr.) di tanah alfisol. Caraka Tani: Journal of Sustainable Agriculture, 17(1), 1-9. https://doi.org/10.20961/carakatani.v17i1.201 02

Nurland, F. (1986). Pemasaran produk pertanian. Ujung Pandang: Lephas Unhas.
Nyambo, B., \& Ligate, E. (2013). Smallholder information sources and communication pathways for cashew production and marketing in Tanzania: An ex-post study in Tandahimba and Lindi rural districts, Southern Tanzania. The Journal of Agricultural Education and Extension, 19(1), 73-92. https://doi.org/10.1080/1389224X.2012.7460 04

Shumeta, Z., Urgessa, K., \& Kebebew, Z. (2012). Analysis of market chains of forest coffee in southwest Ethiopia. Academic Journal of Plant Sciences, 5(2), 28-39. Retrieved from https://citeseerx.ist.psu.edu/ viewdoc/download?doi=10.1.1.414.2197\&rep $=$ rep1\&type $=$ pdf

Soekartawi, S. (1989). Prinsip dasar ekonomi pertanian teori dan aplikasi. Jakarta: Rajawali Pers.

Suratiyah, K. (2006). Ilmu usahatani. Jakarta: Penebar Swadaya Grup.

Westlake, M. (2005). Mengatasi kendala pemasaran dan pengolahan agrifood export: Panduan untuk analisis kebijakan dan perencana. Buletin Layanan FAO, 160.

Widiatmaka, Ambarwulan, W., Sutandi, A., Murtilaksono, K., Munibah, K., \& Daras, U. (2015). Suitable and available land for cashew (Anacardium occidentale L.) in the island of Lombok, Indonesia. Journal of Applied Horticulture, 17(2), 129-139. Retrieved from https://repository.ipb.ac.id/handle/123456789/ 76533

Widiatmaka, Sutandi, A., Iswandi, A., Daras, U., Hikmat, M., \& Krisnohadi, A. (2014). Establishing land suitability criteria for cashew (Anacardium occidentale L.) in Indonesia. Applied and Environmental Soil Science, 2014, 743194. https://doi.org/10.1155/2014/ 743194 